\title{
Locally-Generated Revenue as A Capacity Parameters of New Regional Autonomy Management
}

\author{
Titi Darmi \\ Faculty of Social and Political Science Muhammadiyah University, Bengkulu, Indonesia \\ titidarmi@umb.ac.id
}

\begin{abstract}
Non-human resources play a role in the implementation of the New Autonomous Region (DOB) one of which is the financial resources of the region. In order for the financial capacity of the region can be managed optimally then the appropriate method is to increase its management capacity. The study was conducted in Seluma District as the autonomy mandate of new autonomous regions. The objective of the research is to analyze the extent of the financial management capacity of Seluma Regency as a DOB provider. The research approach is done by qualitative descriptive method, data source is derived from secondary data in the form of, records of financial condition, documentation, financial report that is Report of Result of Inspection (LHP) from BPK, report of $A P B D$ realization and regulations related to financial management implementation. Primary data comes from interviews and FGDs to informants. Data analysis through data collection, data condensation, data presentation and decision making or data verification. The results show that the financial management capacity of Seluma Regency has not been done effectively and efficiently, confirmed by the following conditions: 1) the results of supervision of the implementation of the work program found many cases of TGR; 2) low PAD that only contribute 3\% range to APBD; 3) financial management got WDP opinion from BPK during last 3 years.
\end{abstract}

Keywords: new autonomous region, capacity, financial management 


\section{INTRODUCTION}

The performance of the New Autonomous Region (DOB) has a low performance (Directorate General of Regional Autonomy of Kemendagri RI, 2011) based on the condition, so the Central Government undertakes a temporary suspension of the formation of DOB (Ministry of Home Affairs of the Republic of Indonesia, 2014); (Kompas, 2015). Many factors affecting the low level of DOB performance are the sharing of local resources between autonomous regions and unequally parent regions of both human and non-human resources (Darmi, 2017). It is urgent for the commitment of DOB regional leaders to enable DOB to adapt to other areas (Darmi, 2016). Nevertheless, the performance of DOB will be felt by the public if the stakeholders prioritize the public interest-oriented development program (Firman, 2013).

The policy of the formation of the new autonomous regions is a wise policy undertaken by the central government (Darmi, 2016) in order to accelerate the objectives of the 1945 Constitution namely the welfare of the people. In addition, the mandated DOB Act can manage the potential of resources owned by the region, for the prosperity of its people. Establishment of new autonomous regions (DOB) implies the full authority to manage regional contents in accordance with regional characteristics. The main purpose of the establishment of new autonomous regions to realize regional independence. The meaning of independence ie the region has the ability to finance regional development. This means that regions given autonomous mandates have a good independence in the process of implementing development and have no dependence on financing development by the central government. In addition, DOB organizers are able to increase / strengthen regional institutions that directly impact on the quality of development, the basic services that are directly felt by the community. The success of new autonomous regions is reflected in the level of community welfare (Directorate General of Regional Autonomy Ministry of Home Affairs, 2011).

Seluma District granted a mandate by Law Number 3 Year 2003 as the organizer of DOB, the selection of the location of this study, reinforced by the unique facts of Seluma Regency at the age of 14 , has a lagging development among the other 6 (six) DOBs in Bengkulu Province. The DOB performance indicator is the welfare of the community by looking at how high the Development Index of human is (IPM), in 2013 Seluma District keeps 11th place in 11 regencies / cities in Bengkulu Province (BPS Bengkulu Province, 2013), in 2015 Seluma District HDI level still occupies the lowest position of regencies / cities in Bengkulu Province (Table 1).

IPM is a standard used by the United Nations (UN) in measuring the success of a region. HDI in Seluma (see table 1) is in the lowest category compared to other regions. If the analysis of Bengkulu City which is the provincial capital is a border with Seluma, to go to the capital city of Seluma not exceeding the distance of 1 hour. The range between IPM Seluma and Kota Bengkulu is significant, that is 13.75. To catch up from other regions, Seluma must be able to raise the HDI number each year at least by 0.5 points.

Seluma Regency is a new autonomous region resulting from the expansion of the region of South Bengkulu Regency. As District DOB Seluma faces various problems such as the financing of government administration is still very dependent on central and provincial government subsidy. The above description is a common thread that should occur but not in accordance with the existing reality / empirical data (das sollen / das sein). The purpose and objectives of the study to analyze the extent of financial management capacity of new autonomous regions in Seluma District.

\section{Implementing DOB}

The main task of DOB organizers is to carry out the mandatory and optional affairs 
Titi Darmi - Locally-Generated Revenue as A Capacity Parameters .....

Table 1. IPM of district/city in Bengkulu Year 2015

\begin{tabular}{cll}
\hline No & autonomous regions & Index score \\
\hline 1 & Bengkulu Selatan & 68,57 \\
2 & Rejang Lebong & 67,51 \\
3 & Bengkulu Utara & 67,46 \\
4 & Kaur & 64,47 \\
5 & Seluma & 63,41 \\
6 & Mukomuko & 65,77 \\
7 & Lebong & 64,72 \\
8 & Kepahiang & 65,45 \\
9 & Bengkulu Tengah & 64,68 \\
10 & Kota Bengkulu & 77,16 \\
\hline
\end{tabular}

Source: BPS Provinsi Bengkulu, 2015

mandated by the Regional Autonomy Law and Law Number 23 Year 2014 on Regional Government. The mandatory functions of the autonomous operator are to carry out basic services such as the implementation of education, health, housing and others, concerning the basic needs of the community, while the obligatory functions of non basic services (affairs of choice) is an affair organized in cooperation between the Regency and the Province in order to dig leading sectors of DOB, for example, tourism, agriculture, plantations and others (Darmi, 2017).

The formation of DOB is seen as an appropriate strategy to respond to community demands and as a strategy to strengthen the regional economy in order to strengthen the national economy (Mardiasmo, 2004). In the implementation of DOB, the stakeholders are required to run the wheels of government efficiently and effectively, able to encourage community participation in development, and improve equity and justice by developing all the potential of the region. The success of the new autonomous regions can not be separated from the financial capacity of the regions which is one of the important indicators in implementing the new autonomous regions.

The ability of the new autonomous regions to carry out such affairs reflects how to manage their finances. Financial management of DOB is contained in the Regional Budget (APBD), which describes the ability of local governments to finance the implementation of development tasks.

DOB is required to be able to finance the local government. This capability reflected the level of dependence of new autonomous funding on central government transfers. This means that the new autonomous regions have smaller proportions and Local Revenue (PAD) should be a substantial contribution to the portion of local revenue sources. PAD is a benchmark as well as an indicator of success in the implementation of DOB (Mardiasmo, 2004).

PAD optimization is significantly influenced by organizational culture, organizational performance that culminates in apparatus performance (Darmi, 2013). Increasing the performance of the apparatus as a rare and the effort that needs to be done so that the financial capacity of the region, financial management can be done effectively and efficiently. Increasing the source of PAD can also be done by increasing the number of objects and subjects of taxes and or other regional levies that are considered to have the potential to be a source of PAD.

PAD indicates how high the economic growth of the community (Asnariza \& Hamzah, 2014), the intervention of the Regional Government still plays an important role in supporting the economic growth of the community. Without a concrete economic development program from the Local 
Government, it is difficult for regions to progress in the economic field (Muhammad Mujtaba Habibi, 2015). Areas that can be used as indicators in the economic growth of the community, for example: the development of the agricultural sector, the development of mining and energy sector, the development of industrial sectors, the development of the tourism sector, and others. In addition, the indicator of the quality of public services is the target and target of the implementation of DOB.

\section{Capacity Concept}

The capacity to understand how the autonomous regions can improve their capability in implementing the new autonomous regions through capacity building is done through individual capacity building (HRM), organization / institution and system. In order to ensure continuity of the DOB implementation process in order to achieve the objectives of the new autonomous regions, it is important to carry out capacity building as a strategy (Brown \& Macintyre, 2001). The capacity building of the government is done by improving the human resources of the apparatus, the formation of an innovative organization and system (I Putu Pradana B.Y.P.I, 2014). In managing important organizations, programmatic and continuous capacity building (Berliner, Greenleaf, Lake \& Noveck, 2015) elements of internal and external organizational capacity are sought to increase capacity to achieve organizational goals (Horton et al., 2002 ); (Link, 2007).

In increasing the capacity of the dominant leadership role (Darmi, T, 2016), the chief factor that greatly influences how far the capacity can be done (Horton, 2003), according to horton one element of institutional capacity can be seen from the financial capacity. In order for the finance of the new autonomous regions to be managed optimally, it is necessary to have a strategy / tool, by strengthening the human resource capacity of its apparatus, strengthening the institutional / reform and strengthening system in the form of regulation making.
Local government financial management capacity can be interpreted as an effort to build organizations, systems, partnerships, people and processes correctly to run a particular agenda or plan (Brown \& Cloke, 2004). The result, will be useful, and have a positive impact. In the context of local government financial management capacity, the capacity is directed to: 1) develop the skills and individual competencies as financial managers so that each individual is capable of carrying out the duties and responsibilities it carries; 2) institutional reform as an effort, processes into the authority / authority of organizational units in order to achieve the goals of each organizational unit; 3 ) maximizing and strengthening external factors such as building cooperation on the other side (development and strengthening of external links) in order to grow partnerships intensively, extensively, and solid.

\section{Financial Management}

The new paradigm of state financial management that provides the widest possible power and opportunity to manage the region's financial resources. Government Regulation (PP) No. 58/2005 on Regional Financial Management, defined as Regional Finance is all the rights and obligations of the Region in the context of the implementation of Regional Government which can be assessed by money including all forms of property related to the rights and obligations of the region.

All stakeholders involved should understand the principles of local financial management. conducted in an orderly, lawabiding, efficient, economical, effective, transparent and accountable manner by taking into account the principles of justice, fairness, and benefit for the community. Local financial management has an important role in representing all political and economic activities and policies of regional governments. In order for financial management to produce as expected then the importance of transparency and accountability of local financial management. Local financial management has consequences 
for new autonomous regions such as changes in approaches to budgeting that typically adopt traditional budgetary patterns to change using a performance-based budgeting approach by applying effective and efficient financial management.

In general, information disclosure on APBD management is still very low (Kimura, 2001). The demand for changes in financial management with the intention that public finance be done transparently by basing the concept of value for money so as to create public accountability (Mardiasmo, 2004). DOB financial management will have implications for improving APBD management, including the process of drafting, approving, implementing, overseeing and accounting for budget implementation that will contribute to the welfare of society (Machmud \& Kawung, 2014).

Financial management is reflected in APBD prepared in accordance with the needs of governance and local revenue capability. Preparation of APBD as directed to Regional Development Work Plan (RKPD) in order to realize the service to the public for the achievement of the purpose of state. APBD has the functions of authorization, planning, supervision, allocation, distribution, and stabilization. APBD, APBD change, and accountability of APBD implementation every year is determined by regional regulation (Mardiasmo, 2004).

APBD compiled by the Regional Government is submitted for approval to the Regional People's Legislative Assembly, the approved APDB is incramental to a performance-based budget in accordance with the demands of reform, its implementation is guided by the principles contained in the legislation. The success of financial management that begins with the preparation and ends with the accountability report APBD implementation, should be a guide and used as a tool for determining the amount of income and expenditure, decision-making tools and development planning, the tool of the authority of APBD in the future and as a standard measure for performance evaluation and coordination tool for all activities in various work units. APBD is a fundamental part of policy instruments in implementing regional development (Rofikah, N, 2006).

In addition, the financial management of the new autonomous regions government also saw how much PAD can contribute to APBD. Locally-generated revenue(PAD) should be a substantial contribution to the portion of local revenue sources. PAD is a parameter and an indicator of success in the financial management capacity of the new autonomous regional government.

From some previous studies above, no one has yet examined how the special financial management capacity of the new autonomous region. Financial management capacity is an urgent thing done by the new autonomous regions. In view of all the limitations in the implementation of the new autonomous regions and to optimize all potentials there is a need for facilities through capacity building especially the financial management capacity. This study aims to find out how far the New Autonomous Region Financial Management Capacity (DOB) in Seluma District of Bengkulu Province. .

\section{METHODS}

Research method of this research is descriptive qualitative research method. Sources of data in this research are: 1) secondary data which sourced from records of financial condition, documentation of result of meeting conducted by BPKAD, financial report that is Result of Inspection Report (LHP) from BPK, Realization report of APBD and regulations related to the implementation of financial management; 2) primary data that is done by interview and Focus of Grouf Discussion (FGD) to informant which the researcher think is competent to planning, management and evaluation of finance and informant that oversees the implementation of financial management both mandated in the Law 
Table 2. APBD growth at the age of 13 year DOB

\begin{tabular}{lcc}
\hline No & Year & Rupiah in APBD \\
\hline 1 & 2003 & $17.623 .900 .000,-$ \\
2 & 2004 & $96.741 .562 .576,-$ \\
3 & 2005 & $129.393 .796 .480,-$ \\
4 & 2006 & $265.444 .712 .518,-$ \\
5 & 2007 & $325.771 .001 .000,-$ \\
6 & 2008 & $388.999 .352 .936,-$ \\
7 & 2009 & $392.241 .762 .755,-$ \\
8 & 2010 & $403.165 .030 .551,-$ \\
9 & 2011 & $503.835 .036 .720,-$ \\
10 & 2012 & $478.237 .568 .920,-$ \\
11 & 2013 & $544.429 .269 .243,-$ \\
12 & 2014 & $665.394 .450 .772,-$ \\
13 & 2015 & $695.179 .866 .165,-$ \\
\hline
\end{tabular}

Source: DPPKAD Seluma district, 2016

namely DPRD and social organization (NGO) Interviews are conducted on an ongoing basis after enduring repetitive and saturated information.

Informants in this study as many as 18 people, in determining infoman researcher using purposive sampling method, with approach based on criteria (Patton, M.Q, 2009). The informants the researcher selects are those who are considered to have a lot of information and know a lot about capacity building capacity of financial management. Researcher grouping 2 characteristic of informant consist of; 1) people who know the real, directly involved with the financial management that is, the Secretary of the region (Sekda), Head of BPKAD, Secretary BPKAD, Head of Asset Management, Accounting Staff BPKAD, Chief Inspectorate, Head of evaluation, Auditor Region 1;2) informants who contribute to the oversight of financial management ie Vice Chairman of DPRD, Chairman of Commission III of DPRD and 5 members of DPRD and Chairman of NGO Segay, Chairman of NGO Mata Corruption Smash (MCS) Mr. Herwan and Kamsiatun mother community leaders as well as village head.

To understand the implementation of the financial management capacity of Seluma
Regency, the first thing I do is to visit and consult with the Secretary of the Region (Sekda) as an official who has the authority and responsibility in financial management. Then continue to visit the informant head of BPKAD as the executor as well as in charge of financial management, then continue by visiting the staff below it and ending with a visit to the auditor region 1 (one)) who menangani supervise the implementation of work program management. For informants of 2 (two) characteristics, the researcher visited the informant of the DPRD (FGD), then visited the community organization that participated in the supervision of financial management.

Data analysis is done by 1) arranging data classification both secondary data and primary data; 2) Condensate data to compile, sort and build data analysis performance; 3 ) the researcher performs data presentation as well as data confirmation and deepening of data analysis; 4) the researcher made the conclusion by doing the data analysis in accordance with the construction of the discussion of research results (Miles, M.B.Huberman, A.M., 2014).

\section{FIINDINGS AND DISCUSSION}

One aspect of Seluma District Government that must be carefully regulated is the issue of local financial management and local budgets. 
Titi Darmi - Locally-Generated Revenue as A Capacity Parameters .....

Table 3. PAD Comparison in APBD for 5 Years

\begin{tabular}{|c|c|c|c|}
\hline \multirow{2}{*}{ No } & \multirow{2}{*}{ Year } & \multicolumn{2}{|c|}{ Source of income } \\
\hline & & Realization PAD & Central Transfer \\
\hline 1 & 2010 & $5.519 .577 .177,46,-$ & 342.674.497.573,97,-- \\
\hline 2 & 2011 & 5.535.533.741,35,- & 437.901.281.148,23,- \\
\hline 3 & 2012 & 10.721.155.674,78,- & 475.681.035.051,05,- \\
\hline 4 & 2013 & 16.756.639.779,93,- & $541.256 .382 .578,67,-$ \\
\hline 5 & 2014 & 25.607.988.161,57,- & $611.440 .890 .161,09,-$ \\
\hline
\end{tabular}

Source: DPPKAD Seluma District, 2016.

Local budgets are a specific work plan (one year). Regional budgets are APBD approved by DPRD. Applied through RKPD / Renja in every Organization of Regional Devices (OPD). In the management of the budget is important to do transparency principle. The absence of transparency in APBD usage will make it impossible to monitor the implementation of APBD (Perdana, 2014).

The district budget of Seluma District since its establishment as DOB from 2002 to 2015 shows a significant increase in APBD (Table 2). During 13 years of age of DOB, but in 2012 there was a decrease in the amount of APBD Kabupaten Seluma.

In the process of administering the government, both mandatory and optional affairs reflected in the above APBD are distributed through the Regional Apparatus Organization (OPD) in accordance with the proposed planning through the budgeting stages and approved by the DPRD. The financial capability of Seluma Regency is reflected from the Locally-generated revenue (PAD). Interview with the head of the DPPKAD of Seluma Regency, dated September 26, 2016 stated the following:

Pure PAD Seluma District Government only contributes $2 \%$ to $A P B D$, if PAD is combined totally PAD contributes to $A P B D$ not more than $4 \%$. This means that the Seluma Regency has not been able to organize the process of self-government, because it still has dependence on central transfers in financing the needs of the region.
Statement of DPPKAD Head is supported by Budget Realization Report data for 2010 2014 Seluma District Government (Table 3), it shows the gap between PAD and central transfers. It shows there is an increase in PAD every year although low. The low increase of realization of PAD in 2010 is Rp. 5,519,577,177,46, - while in 2011 the realization of PAD of Rp. 5,535,533,741.35, PAD increment is only Rp. 15.956.563,89, -. Unfortunately, the area with all the potential that exists can only increase the income of household finance class. This means that the related agencies are not serious in working to increase PAD.

The results of interviews with informants explained the crucial factors contributing to the low PAD of Seluma District due to: 1) approximately $50 \%$ of Seluma District have lagging villages, by themselves nothing can be processed to be used as a source of PAD;2) the population of Seluma Regency is still relatively small compared to the total area; 3 ) Tais as the capital of Seluma Regency can not be said as a city, has not had a present market; 4) Seluma Regency has not been able to synergize with private parties (plantations, mining), there is no regulation to utilize CSR; 5) the natural resources potential of Seluma Regency is not directly managed by the local government, such as mining; 6) still low quality of human resources apparatus.

The contribution of PAD to APBD is still very poor, if presented as a whole, $\mathrm{PAD}$ contributes $3 \%$ of APBD. This means that the dependency of costs in the provision of DOB reaches $97 \%$, this is very high category 
Table 4. Seluma Regency Financial Policy Year 2013 and in 2014

\begin{tabular}{lllll}
\hline \multicolumn{1}{c}{ Description } & Budget year 2014 & \% & Budget year 2013 & \% \\
\hline Income: & & & & \\
1. PAD & $24.263 .387 .597,-$ & 3,77 & $17.650 .100 .000,-$ & 3,14 \\
2.Subsidies & $619.739 .098 .852,-$ & 96,23 & $543.635 .143 .516,-$ & 98,86 \\
The total number of & $644.002 .486 .449,-$ & 100,00 & $561.285 .242 .516,-$ & 100,00 \\
Expenditure: & & & & \\
$\begin{array}{l}\text { 1. Operational expenditure } \\
\text { 2.Capital expenditures }\end{array}$ & $505.469 .884 .868,-$ & 68,11 & $462.083 .043 .182,-$ & 70,59 \\
$\begin{array}{l}\text { 3. unforeseen Expenditures } \\
\text { The total number of }\end{array}$ & $235.111 .748 .635,-$ & 31,68 & $187.680 .914 .204,-$ & 28,67 \\
$\begin{array}{l}\text { Acceptance Of Financing: } \\
\text { Use Silpa }\end{array}$ & $1.600 .000 .000,-$ & 0,22 & $4.853 .001 .927,-$ & 0,74 \\
$\begin{array}{l}\text { Financing Expenses: } \\
\text { The inclusion of government capital }\end{array}$ & $542.181 .633 .503,-$ & 100.00 & $654.616 .959 .313,-$ & 100,00 \\
\hline
\end{tabular}

Source: LHP Year 2015 Seluma District

of transfers either from the province or from the central government in order to run the government.

Implementation of the DOB carries consequences for Seluma District to be more independent from both the financing system and in determining the direction of regional development in accordance with the priorities and interests of the community. But the classical reason we often hear that the institutional capacity is still low, due to lack of budget availability. For that it is necessary to receive revenue management regency, so that all the existing potential line can be worked out maximally. In this case Pemkab Seluma has not done it optimally as said by NGO chairman Mr. Herwan:

That PAD Seluma District can be improved if the leadership and the ranks of the district government synergize. Potentials and opportunities are not cultivated, for example, the number of sleeping land around the Seluma District office, if Pemkab Seluma creatively the land can be used as a source of income, or take restibusi car transporting palm oil, I note every passing track is taken illegally 50.000, - rupiah / track, if one day 50 tracks and multiplied by 50.000,
- multiplied again 30 days multiplied by another 12 months, well 1 year only Pemkab have got 90.000.000 money, - that is new from palm transport lho (interview on October 10, 2016).

The statement of the NGO chairman was in line with the statement of the deputy chairman of the DPRD.

Seluma District Leaders do not have the courage, do not have the courage to make the target PAD let alone make the realization according to the target, sleeping land around the office area of approximately 100 ha can produce if managed properly (interview dated September 28, 2016).

The result of the writer's observation, the cause is the policy implementing actors have not maximally utilized, managing the potential of existing resources so that it has very implication to the source of regional income. Taxation reform strategy required as a systematic step to provide services to taxpayers in obedient and perform administrative processes to the fullest. The existence of administrative reform and modernization of the taxation process, has implications for local revenue from the 
tax sector, both personal taxes, physical and business groups. The electronically built system provides convenience and goodness for the community as a service user (Abdullah, 2014).

The low financial condition of Seluma District is one of the obstacles to the achievement of the objectives of the new autonomous regions. The low PAD of Seluma Regency has made Seluma Regency non-self-sufficient and still dependent on subsidies from the central government in financing the implementation of government.

Table 4 explains the financial condition of Kabuma Selen in 2013 and 2014, the financial condition is reflected in the APBD, the data explains that for 2014 receive subsidy of $96.23 \%$ and the year 2013 is $96.86 \%$ which explained that the PAD of Seluma Regency is very small, PAD only contributes to the APBD of $3.16 \%$ in 2013 and $3.77 \%$ in 2014.

$\mathrm{PAD}$ is all revenue earned by the Region from sources within its own territory. PAD is very important as the basic capital of governance and development, therefore it is necessary to mobilize as one component of the source of Regional Income based on the Regional Government Law. Unfortunately this is not handled seriously, confirmed by the small value of PAD which is $3.77 \%$ APBD 2014 , although even so, there has been an increase of $0.63 \%$ compared to $3.14 \%$ APBD 2013 .

If PAD is small (only $3.77 \%$ APBD) then it can be said there is a problem of regional economic independence. The commitment of local governments to reduce dependence on provincial and / or central government subsidies is important to be questioned. This is evidenced by the financial management system there is no increase in Financing Expenditure from Pemda Pemendaan Pemda that only Rp 5 billion or $20.61 \%$ of PAD APBD 2014.

Although it is worthy of Capital Expenditure increased from $28.67 \%$ APBD 2013 to 31.68 APBD 2014 or increase the value of spending $20.17 \%$ or Rp 47.430 .834 .431 , When compared with Operational Expenditure then Capital Expenditure is still smaller. This is similar to the pattern of the budget system of most LGs, namely the routine budget is greater than the development budget.

The data shows the total income as stated in APBD of Seluma Regency in 2015 amounting to Rp.695,179,866,165, - PAD is Rp. 25.607.988.161,57, - or 3.62\%. So that the amount of central and provincial government subsidy amounted to Rp.669.571.878.004 or $98.38 \%$. the ratio of local financial independence and the degree of decentralization of finance is very less "3.62\%". Compared to 2014, the PAD of Seluma Regency contributed 3.77 PAD contributed $3.77 \%$ of APBD, meaning that a decrease of $0.15 \%$ of local revenue sources was reduced in fiscal year 2015.

The above shows no seriousness of the policy implementers (especially the DPPKAD) in working to achieve the vision of the DPPKAD mission which one of its mission is to increase the PAD Pemkab Seluma. Decrease in PAD or regional revenue sources to indicate the cost of development in Seluma District will always have a very high dependence on transfers from the central center.

Even though it should be grateful Capital Expenditures increase from 28.67\% APBD 2013 to 31.68 APBD 2014 or increase the value of expenditure $20.17 \%$ or Rp 47.430 .834 .431 , When compared with Operational Expenditure then Capital Expenditure is still more small. This is similar to the pattern of the budget system of most LGs, namely the routine budget is greater than the development budget. The success of DOB District Government can be said to succeed if the budget of Expenditure of Operational and Expenditure Capital is balanced or budget of Capital Expenditure or Development is bigger (Word: 2013). If this word happens to Seluma Regency then it can be assumed that Regional economy can be encouraged to experience greater growth even beyond national economic growth rate. Many areas have proven themselves beyond that.

There has been a decrease in the ratio of Unexpected Expenditures from $0.74 \%$ of 
APBD 2013 to $0.22 \%$ APBD 2014 or a decrease in the amount of expenditure amounting to $\mathrm{Rp}$ $3,253,001,927$. This indicates the improvement of Regional Planning which can already predict all local budgets needed so that it can lower the Unexpected Shopping. This is also evidenced by the declining use of SILPA APBD 2013

Rp 244,331,716,797, - into the use of SILPA APBD 2015 Rp 103.197.147.054, or decreased by Rp 141,134,569,743, - one indicator of success by reducing the SILPA $57.76 \%$ of SILPA APBD 2013.

The financial management system of Seluma Regency based on Permendagri Number 13 Year 2006, through budgeting and administration. Administration is done by calculating income, spending and reporting. While the financial audit system is done based on Law Number 15 Year 2004, the audit is performed on the financial statements of the regency periodically reviewed by internal audit and then submitted through the accountability of the APBD to the DPRD. With budget constraints, Seluma District government should be able to manage the budget effectively and efficiently. The principles of financial management must be obeyed by all stakeholders of budget management (Treasurer in each OPD).

In the financial management of indicators of performance achievement performance of Seluma District Government as an effort to improve the quality of accountability, Seluma Regency Government is annually obligated to make: 1) financial report; 2) development report; and 3) LAKIP. Particularly for financial management, conducted by BPK, Seluma District Government has not yet received a WTP opinion from BPK audit results. Reports by 2015 , the District Government of Seluma Regency again received WDP, did not reach the set targets and became a problem for the financial management of the District Government of Seluma Regency.

Assessment of financial statements of local government administrations given opinion by BPK based on internal audit report of BPK.
Note BPK branch of Bengkulu in 2015 Seluma Regency won a fair opinion with the exception (WDP). In addition, the results of the supervision of the Inspectorate of Seluma Regency and the inspectorate of Bengkulu Province are still a lot of Compensation Findings (TGR) from the results of the work program implementation, it is necessary attention to solve the problem on the examination findings.

Year 2015 there are several records of the results of BPK assessment, namely: First Pemkab Seluma not fully implement the accounting standards of government based on accruals. The use of an accrual basis is required to provide comprehensive and credible financial reports to stakeholders (Tarigan, 2013). Second, the budgeting mistakes of some shopping accounts in some local governments. Third, the administration and presentation of assets has not been optimal in supporting the presentation of local government financial statements.

In addition, examination findings on compliance with laws and regulations, among others, unclear assets of status and entitlements to the potentially missing management contributions, management of grant expenditures, social assistance and financial assistance to local governments in fiscal year 2015 have not been supported by accountability for use funds and not according to the provisions. Furthermore, the execution of the work is not in accordance with the contract and indicates harm to the region, the number of findings that become cases and overpayment of work packages paid to third parties and has not been subject to sanctions penalty delay.

The above information shows that Seluma Regency has not yet conducted optimal financial management by observing the principles of efficiency, effectiveness, transparency, and public accountability. It is advisable that the management of local government finances must fulfill the principle of public accountability at least include: 1) accountability of honesty, in relation to avoiding the misuse of office by officials in the use and utilization of regional 
finances; 2) legal accountability related to compliance with the law that is to comply with all existing regulations in the use of state finances; 3) process accountability, in relation to the compliance of stakeholders, comply with all procedures used in implementing the use of regional finance; 4) accountability of policies, in relation to the accountability of the Regional Government to the DPRD and the community over the policy on the use and utilization of regional finances.

The publication of the autonomy law has implications for the increased authority of regional governments, the authority of excavation and the management of potential sources of income (eg taxes and user charges) also increase. In other words, the decentralization of authority has a relationship perpendicular to fiscal decentralization as a precondition for the success of regional autonomy. Under the legislation on fiscal decentralization, local sources of income include taxes and user charges (Law 34/2000), balance funds (Article 6 of Law Number 25/1999), loans (Government Regulation No. 107 of 2000), as well as the revenue tax revenue section (Decree of the Minister of Finance No. 6 / KMK.04 / 2001). With base financial management as above, the region is expected to be independent of the central government, as well as to strengthen the implementation of autonomy programs in the region.

Meanwhile, legislation regarding regional financial management of PP No. 58 of 2005, followed up by Domestic Regulation of Domestic Affairs Regulation No. 59/2007, the second amendment of the Minister of Home Affairs Regulation No. 13 of 2006 on Guidelines for Regional Financial Management, APBD is the basis of local financial management in period of 1 (one) budget year consists of regional income, regional expenditure, and regional financing. As Regional Finance is the policy instrument of APBD management that occupies a central position in the effort of developing capability and effectiveness of local government. APBD is used as a tool to determine the amount of income and expenditure, to assist decision-making and development planning, future expenditure authorization, sources of standard measure development for performance evaluation, tools to motivate employees, and coordination tools for all activities of various work units (Mardiasmo, 2004).

Referring to the above opinion it is important to realize the ability and independence of the region and strengthen the structure of regional revenue, inevitably the role of PAD should be improved, because it is one of the benchmarks ability and reflection of regional self-reliance. The lack of acquisition of PAD in Seluma District is considered as a barrier to the success of the implementation of new autonomous regions.

The independence of Regional Finance indicates the level of ability of a region in financing government activities, development and services to people who have paid taxes and levies as a source of income required by the region. The ratio of self-reliance is indicated by the amount of the original income of the region compared to the regional income derived from other sources.

\section{CONCLUSION}

The current condition, the management of the district finance of Seluma Regency as the organizer of the new autonomous regions has not been managed effectively and efficiently by adopting honesty value, based on inpektorat audit almost all of the work program implementation found TGR. In addition, many corruption cases indicate the implementation of work programs based on BPK audit so that the financial management of Seluma Regency gets WDP opinion in $2013-2015$ by BPK. This means that the management of the regional government of Seluma Regency has not yet implemented the budget management system and financial management based on the basic principles. Basically the financial management of local government should adhere to the 
principles - principles: 1) comprehensive and discipline; 2) flexibility; 3) predictable; 4) information; 5) transparency and accountability (World Bank: 2008). The financing of the governance of new autonomous regions in Seluma Regency is still highly dependent on central and provincial subsidies because PAD only accounts for $3 \%$ of APBD.

In the future, as an evaluation material for Seluma District Government policy stakeholders should work harder and more optimally, focusing on development planning processes from village to district level to improve local economic independence by increasing productive activities so that it is expected to reduce dependence on subsidy. The independence of a region shows the level of ability of a region in self-financing government activities, development and service to the community and it is reflected in how high the PAD is gained.

\section{REFERENCE}

Abdullah, H. (2014). Realokasi Kebijakan Fiskal: Implikasi Peningkatan Human Capital dan Pembangunan Infrastruktur terhadap Pertumbuhan Ekonomi dan Kesejahteraan Masyarakat. Jurnal Bina Praja, 6(2), 117-128. https://doi. org/10.21787/jbp.06.2014.117-128

Asnariza, Abubakar Hamzah, N. S. (2014). Analisis Efesiensi Dan Efektivitas Pemungutan Pendapatan Asli Daerah Kota Sabang. Jurnal Ilmu Ekonomi Pascasarjana Universitas Syiah Kuala, 2(4), 77-85.

Berliner, D., Greenleaf, A., Lake, M., \& Noveck, J. (2015). Building Capacity, Building Rights? State Capacity and Labor Rights in Developing Countries. World Development, 72, 127-139. https://doi. org/10.1016/j.worlddev.2015.02.018

BPS Provinsi Bengkulu. (2013). Provinsi Bengkulu Dalam Angka. Bengkulu: BPS Kabupaten Seluma.

Brown, E., \& Cloke, J. (2004). Neoliberal Reform, Governance and Corruption in the South : Assessing the International Anti-Corruption Crusade.

Brown, L., Lafond, A., \& Macintyre, K. (2001). Measuring Capacity Building, (March), 919-966. Retrieved from www.cpc.unc. edu/measure

Darmi, T. (2013). Budaya Organisasi, Kinerja Organisasi, dan Kinerja Aparatur. Jurnal Administrasi Pembangunan FISIP UNRI, 2 Nomor 1, 1-114. Retrieved from download.portalgaruda.org/article. php? article $=146116 \& v a l=2266$. .,Suwitri, S., Yuwanto \& Sundarso. (a). 2017. Capacity Building as Accelerator for Improving Autonomous Region Recently Knows as ( DOB ): Case Study in Seluma Distrcit Bengkulu Province, Indonesia. Journal of Public Administration and Governance, 7(3), pp.100-117.

, \& Suwitri, S., (b). 2017. Strengthening the Capacity of Human Resources Apparatus in the Implementation of New Autonomous Regions. European Journal of Social Sciences, Vol. 55 No, pp.427-438. Available at: http://www. europeanjournalofsocialsciences.com/. .Suwitri, S., Yuwanto \& Sundarso. (2016). The Capacity Of Local Leaders To Improve Performance Of New Autonomous Region (DOB) in Indonesia (Case Study on The Regional Province of Bengkulu Seluma Regency). In Yan Xioang (Ed.), Innovation in Regional public Service For Sustainability ( $\mathrm{p}$. 104). Kunming: Atlantis Press. https:// doi.org/10.29991/icpm-16.2016.27

Direktorat Jenderal Otonomi daerah Kemendagri RI, D. (2011). Laporan Hasil Evaluasi Daerah Otonom Hasil Pemekaean (EDOHP). Jakarta.

Firman, T. (2013). Territorial splits ( pemekaran daerah ) in decentralising Indonesia, 2000-2012: Local development drivers or hindrance? Space and Polity, 17(2), 180-196. https://doi.org/10.1080/13562 576.2013.820373 
Horton, D. (2003). Evaluating Capacity Development: Experiences from Research and development Organizations Around the World, Ottawa; International Development Research Centre (copyright:). Netherlands: International Service For National Agricultural Research.

Horton, D., Alexaki, A., Bennett-lartey, S., Brice, K. N., Campilan, D., Carden, F. Duong, L. T. (2002). Organizations around the World.

Kementerian Dalam Negeri Republik Indonesia. (2014). Pembentukan Daerah Otonomi di Indonesia. Jakarta. Retrieved from otda.kemendagri.go.id/CMS/Images/ SubMenu/totalDOB

Kimura, H. (2001). The Capacity Building For Democratic Development Local Governance. Jurnal Kebijakan Dan Administrasi Publik UGM, 5 Nomor 1.

Kompas. (2015, July). Jakarta, Mendagri Perketat Pemekaran Daerah Baru. Kompas. Jakarta.

Machmud, M., \& Kawung, G. (2014). Analisis Kinerja Keuangan Daerah Di Provinsi Sulawesi Utara Tahun 2007-2012. Jurnal Berkala Ilmiah Efisiensi, 14(2), 1-13.

Mardiasmo. (2004). Otonomi \& Manajemen Keuangan Daerah. In ke 2. Yogyakarta: Andi Offset.

Michael Quinn Patton. (2009). Metode Evaluasi Kualitatif. (P. K. Penerjemah Budi Puspo
Priyadi, Ed.) (ke 2). Yogyakarta: Pustaka Pelajar Offsr.

Miles, M.B.Huberman, A.M., J. (2014). Qualitatif Data Analysis. A Methods Sourcebook. California: Sage Publication.

Muhammad Mujtaba Habibi. (2015). Analisis Pelaksanaan Desentralisasi Dalam Otonomi Daerah Kota/Kabupaten. Jurnal Pendidikan Pancasila Dan Kewarganegaraan, 28 Nomor 2, 117125.

Pradana, I,P,Y, Bumi. (2014). Transparansi Birokrasi dalam Pengelolaan APBD di Kota Kupang. Jurnal Kebijakan Dan Administrasi Publik UGM, 18 Nomor 2,185 .

Taut, S. (2007). Studying SelfEvaluation Capacity Building in a Large International Development Organization. American Journal of Evaluation, 28(1), 45-59. https://doi. org/10.1177/1098214006296430

World Bank., Frengler, W., Ihsan,A \& Kaiser, K. (2008). Managing Post-Disaster Reconstruction Finance (Internatioanal Experience in Public Financial Management). The World Bank, East Asia and the pacific. diakses, 28 Januari 2016. www. recoveryplatform.org/ assets/publication/financing post disaster reconstruction WB.pdf 